\title{
DESAIN KOMUNIKASI PROMOSI PRODUK BABY FISH SISTEM MINA PADI DI DESA WISATA ORGANIC LOMBOK KULON, KECAMATAN WONOSARI, KABUPATEN BONDOWOSO
}

\author{
1) Tanti Kustiari, 2) Rizal, Ariesia A Gemaputri \\ Politeknik Negeri Jember \\ 1,2 tanti_ipb@yahoo.com
}

\begin{abstract}
ABSTRAK
Sistem mina padi merupakan cara pemeliharaan udang atau ikan di sela-sela tanaman padi (Integrated Fish Farming/IFF), sebagai penyelang diantara dua musim tanam padi, atau pemeliharaan ikan sebagai pengganti palawija di persawahan. Pengabdian ini bertujuan untuk memecahkan persoalan mitra melalui terciptakan hubungan kemitraan usaha atau System usaha tani terpadu hulu - hilir. Menciptakan keterjalinan bisnis antara mitra produsen (suplay baby fish) dengan mitra konsumen (demand). Mitra pengabdian di Desa Lombok Kulon membutuhkan dukungan Ipteks spesifik untuk mengatasi persoalan perluasan jaringan pemasaran, mempertahankan pelanggan, memudahkan komunikasi (pesanan) pelanggan, perluasan jaringan kerjasama pengembangan kelembagaan, pengembangan masyarakat. Selain itu membutuhkan peningkatan kompetensi SDM, dimana mereka membutuhkan dukungan teknologi informasi berbasis website dan membutuhkan pendidikan non formal komunikasi bisnis kuliner untuk meningkatkan wawasan, ketrampilan serta mendorong kreativitas tenaga kerja untuk memberi pelayanan terbaik.
\end{abstract}

Kata kunci: Desain Komunikasi, Produk, Baby Fish, Lombok Kulon

\section{PENDAHULUAN}

Pertanian organik yang diterapkan oleh kelompok "Tani Makmur" telah memperoleh sertifikasi organik dari Le SoS namun dengan produksi yang kadang sangat rendah menjadikan produktivitas usaha budidaya padi organic tidak maskimal. Menurut Ketua kelompok Tani Makmur, produksi padi tiap panen tidak sama. Seringkali hasil panen padi hanya 6- 7 ton/ha, padahal semestinya $10-12$ ton/ha. Adanya penerapan Ipteks mina padi baby fish organik diharapkan : (1) menambah produksi padi organik, (2) menambah penghasilan, (3) meningkatkan kesuburan dan iklim mikro yang dapat membantu kesuburan tanah dan meningkatkan produktivitas padi. Mitra II membutuhkan dukungan Ipteks spesifik untuk mengatasi persoalan perluasan jaringan pemasaran, mempertahankan pelanggan, memudahkan komunikasi dengan pelanggan, perluasan jaringan kerjasama dan pengembangan kelembagaan, serta pengembangan masyarakat. Selain itu membutuhkan peningkatan kompetensi SDM. Mitra II membutuhkan dukungan teknologi informasi berbasis website dan membutuhkan pendidikan non formal komunikasi bisnis kuliner untuk meningkatkan wawasan, ketrampilan serta mendorong kreativitas tenaga kerja untuk memberi pelayanan terbaik.

Desain komunikasi promosi memperhatikan penggunaan bahasa menarik,persuatif dan memperhatikan penyusunan tata letak jenis komunikasi verbal, gambar, visual, numeric yang baik sehingga pesan promosi mengundang khalayak untuk melihat,membaca. Desain komunikasi promosi sebagai bahan untuk menyampaikan berbagai informasi, harapan, tawaran melalui media cetak dan digital (internet).

1. Pembuatan media cetak (Leaflet)

Diawali dengan tahap perencanan yaitu (1) peralatan seperti computer, CPU atau laptop, alat cetak hasil. (2) mempersiapan bahan kertas ukuran folio. (3) menyiapkan bahanbahan atau informasi yang akan disampaikan. Tahap Proses (1) mendesain atau menentukan tata letak judul, gambar, informasi, logo, nomer kontak, nama lembaga. (2) melakukan setting dalam bentuk softcopy. Tahap akhir melakukan pencetakan hasil. Kemudian dievaluasi tata letak dan isi materi. Dilanjutkan dengan perbaikan.

2. Pembuatan media digital

Pembuatan media website pondok kuliner desa wisata organik diawali dengan (1) pengenalan apa, manfaat kegunaan website. 
Dilanjutkan dengan (2) menjelaskan apa domain dan hosting dan bagaimana langkah mendapatkannya. (3) bagaimana order nama hosting dan domain. (4) menjelaskan cara setting control panel aea. (5) menjelaskan cara up load file ke layanan hosting. (6) menjelaskan cara configurasi table data. (7) menjelaskan cara confogurrasi admin area.

\section{METODE PELAKSANAAN}

\section{Lokasi dan Sasaran Program}

Kelompok sasaran program IbM adalah kelompok "Mina Usaha” di Desa Lombok Kulon, Kecamatan Wonosari, Kabupaten Bondowoso.

\section{Pelaksanaan}

Pengabdian ini dirancang untuk memecahkan persoalan kedua mitra melalui terciptakan hubungan kemitraan usaha atau System usaha tani terpadu hulu- hilir. Menciptakan keterjalinan bisnis antara mitra produsen (suplay baby fish) dengan mitra konsumen (demand). Keterbatasan pasokan bahan baku dan ketidakkontinyuitasan bahan baku Mitra II dapat teratasi. Program pengabdian membantu mewujudkan cluster bisnis organic di Desa Wisata Organik di mana produksi dan penjualannya dilakukan kelompok-kelompok usaha di bawah kelembagaan Desa Wisata Organik Lombok Kulon.

Keberhasilan program tergantung dari kerjasama antara pelaksana IbM dengan masyarakat kelompok tani organik. Kesepakatan yang dilaksanakan adalah :

(a) Pengusul IbM membantu menyediakan bahan baku ikan organik

(b) Pengusul IbM membantu meningkatkan kapasitas SDM (pegawai) Mitra II dalam memberikan pelayanan prima.

(c) Pengusul IbM membantu peningkatan kapasitas mitra II dalam mendesain komunikasi promosi produk dengan media cetak dan digital.

(d) Pengusul IbM membantu peningkatan kapasitas mitra II dalam pembuatan media website dan brosur.

(e) Pengusul IbM membantu peningkatan kapasitas mitra untuk menggunakan dan mengaplikasikan media digital

\section{Waktu Pelaksanaan}

Kegiatan ini merupakan bagian utama dari kegiatan pengabdian Iptek Bagi Masyarakat.
Pelaksanaan kegiatan pelatihan ini dilaksanakan pada tanggal 17 - 18 September 2016.

\section{HASIL DAN PEMBAHASAN}

Kegiatan pembuatan desain komunikasi promosi produk dilakukan 2 (dua) kali yaitu pertama pelatihan mendesain komunikasi promosi produk tercetak. Kedua pelatihan desain komunikasi produk media digital. Kegiatan tersebut diikuti oleh 10 orang peserta kelompok Mina Usaha. Kelompok yang menekuni bidang pondok kuliner yang memasarkan produk ikan organic desa Lombok Kulon.

Desain komunikasi promosi produk didesain memenuhi kriteria AIDA yaitu komunikasi harus attention atau mampu menjadi perhatian, interest (menarik), desire (menimbulkan keinginan) dan action atau mudah untuk diperoleh. Komunikasi promosi baik media tercetak dan internet dapat memberikan informasi dan pesan-pesan persuasive menawarkan produk-produk ikan baby fish dan produk ikan organic lainnya.

a. Pembuatan Media Tercetak

Kegiatan pembuatan media tercetak diawali dengan menentukan outline deskripsi, pesan persuasive, gambar produk, logo, judul, kegunaan, dokumentasi, lokasi dan penanggung jawab. Setelah itu dilakukan proses penulisan secara tertulis pada lembar kerja microshop office. Setting dan editing dilakukan untuk menghasilkan foster yang indah dan berbobot. Outline Desain Komunikasi Promosi Produk Tercetak adalah sebagai berikut.



Gambar 1. Desain

Pada pelatihan pembuatan media tercetak disampaikan tentang pembuatan outline kemudian dilanjutkan dengan pembuatan desain komunikasi promosi dengan tema aplikasi sistem mina padi dan tema promosi ikan baby fish. 
Pelaksanaan program Ipteks Bagi Masyarakat pembuatan media promosi tercetak dan internet terintegrasi dengan program mina padi. Hal ini bertujuan untuk meningkatkan kemampuan promosi dan pemaksimalan layanan produk-produk organic Pondok Kuliner Desa Wisata Organik Lombok Kulon Kecamatan Wonosari, Kabupaten Bondowoso.

Media komunikasi promosi baby fish olahan dengan media tercetak seperti leaflet, foster. Media tercetak dibuat dengan ketentuan yaitu : (1) ukuran kertas disesuaikan dengan kebutuhan promosi misalkan $40 \mathrm{~cm}$ x $30 \mathrm{~cm}$ agar dapat dibaca dari jarak 1 (satu) meter, (2) jenis kertas tebal laminating agar lebih tahan lama, (3) menggunakan gambar, back ground yang menarik, (4) penggunaan warna-warna yang kontras dan menarik, (5) membuat judul dan pesan persuasive, (6) sampaikan pesanpesan edukatif seperti sehat berawal dari makanannya, ayok budayakan makan ikan setiap hari, (7) cantumkan kegunaan, manfaat produk, (8) uraikan beberapa produk-produk diversivikasi bila ada, (9) cantumkan nama dan kontak yang dapat dihubungi oleh konsumen.

Kegiatan pelatihan menggunakan metode diskusi dan praktik. Peserta diminta untuk membuat desain-desain komunikasi promosi produk dengan tema masing-masing yang diminati seperti membuat desain komunikasi promosi tubing, aneka kerajinan kayu organic, promosi produk ikan lele dll. Peserta membuat desain komunikasi produk sesuai dengan ketentuan outline yang sudah diberikan tim pelatih. Setelah selesai praktik membuat desain komunikasi promosi produk, peserta tampil di depan kelas untuk menjelaskan hasil karya masing-masing. Praktik pembuatan foster dimaksudkan agar peserta disuatu saat nanti mampu melakukan secara mandiri pengembangan kegunaan foster dan leaflet sesuai dengan keinginan/kebutuhan promosi produk-produk baru lainnya milik pondok kuliner.



Gambar 1. Desain Komunikasi Promosi dengan Media Tercetak

\section{b. Pembuatan media Digital (internet)}

Kegiatan pelatihan media internet diikuti oleh 10 orang peserta dari kelompok mina usaha. Materi pelatihan diberikan secara sederhana karena peserta tidak memiliki kompetensi internet sehinggi tim pelatih memberikan materi dasar tentang internet, cara menggunakan, memposting, merubah/mengedit. Pelatihan diberikan agar peserta mampu menggunakan dan mengembangkan untuk keperluan mempromosikan produk ikan baby fish dan produk-produk lainnya dari pondok kuliner.

Website yang dibuat untuk mempromosikan desa wisata organik Lombok Kulon dapat diakses pada alamat www.desawisataorganikbondowoso.com

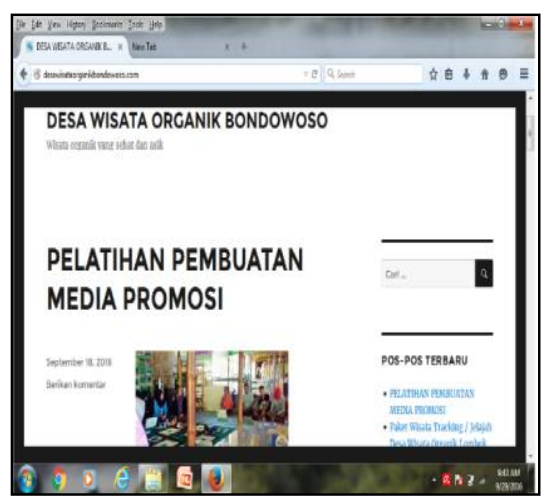

Gambar 2. Desain Website

Website yang telah dibuat tersebut kemudian akan digunakan untuk mempromosikan semua kegiatan di desa organik Lombok kulon, dikelola oleh anggota kelompok Mitra yang bertanggung jawab atas isi dan konten website. Pelatihan mengenai pengelolaan website telah dilaksanakan pada tanggal 18 September 2016 yang diikuti oleh 10 orang anggota Mitra.

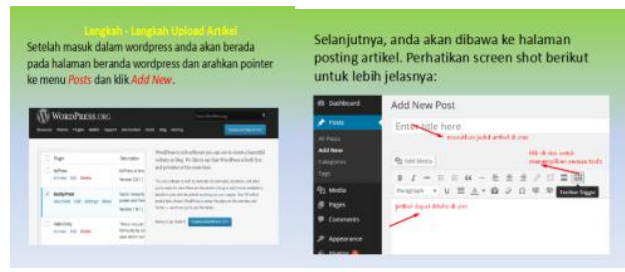

Gambar 3. Materi Pelatihan

Pengelolaan media sosial Instagram ini juga dilakukan oleh anggota mitra dengan cara mengupdate foto-foto kegiatan yang telah 
dilakukan di Desa Wisata Organik Lombok Kulon. Hal ini dilakukan sebagai cara untuk menarik konsumen-konsumen baru agar mau datang ke Desa Wisata Organik Lombok Kulon.

Kegiatan promosi yang kedua dilakukan dengan menggunakan sosial media Instagram dengan alamat www.instagram.com.desaorganiklombokkulon.

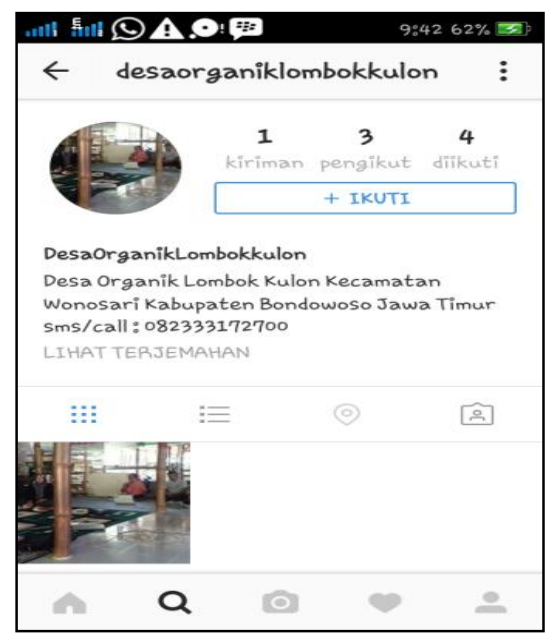

Gambar 4. Media Promosi dengan Instagram

\section{KESIMPULAN}

Kegiatan pelatihan pembuatan media promosi Desa Organik Lombok Kulon dilakukan pada minggu pertengahan bulan September 2016 dengan materi pembuatan desain promosi melalui foster, leaflet, website, dan akun media social instagram. Pembuatan desain promosi sangat penting dilakukan sebagai salah satu cara untuk mempromosikan Desa Organik Lombok Kulon sehingga menarik minat masyarakat umum untuk berkunjung dan berwisata kuliner ke Desa Wisata Organik Lombok Kulon, Kecamatan Wonosari, Kabupaten Bondowoso.

\section{DAFTAR PUSTAKA}

[1] Direktorat Jenderal Perikanan, 1995. Pemeliharaan Ikan dengan Sistem Mina Padi, Departemen Pertania, Balai Budidaya Air Tawar, Sukabumi-

Indonesia,Brosur.http://www.warintek.ristek.g o.id/perikanan/Lain\%20lain/pelihara ikan min a_padi.pdf

[2] Linus Simanjuntak, 2013. Kiat Mengatasi Permasalahan Praktis Usaha Tani Terpadu PATI (Padi, Azolla, Itik dan Ikan). Pola Pertanian Organik Terpadu Dengan Modal, Buku. AGROMEDIA, 2013.

[3] Mugniesyah, SS. 2010. Media Komunikasi dan Komunikasi Massa. Dalam buku Dasar-Dasar Komunikasi. Editor : Aida Vitayala S. Hubeis. Bogor : Penerbit Sains KMP IPB Press.

[4] Mustafa Montazeri, 2012. Inovasi Teknologi Minapadi Dalam Mengurangi Pemanasan Global, Makalah.

[5] Poerwoko Hadi dan Umi Pudji Astuti (2014). Pemeliharaan Ikan Bersama Padi Di Sawah (Mina Padi), Sebuah Potensi Keuntungan Ganda Untuk Petani. Litbang pertanian Bengkulu. Proceding: http://bengkulu.litbang.pertanian.go.id/ind/im ages/dokumen/2014/prosiding13/ikan.pdf

[6] Sumarwan, Ujang, dkk. 2011. Pemasaran Strategik Perspektif Value Based Marketing dan Pengukuran Kinerja. Bogor : Penerbit IPB Press 